\title{
E-Government Project Obstacles in Pakistan
}

\author{
Zulfiqar Haider, Chen Shuwen, and Muhammad Bux Burdey
}

\begin{abstract}
Several governments are trying to implement and enhance reliable electronic government services all around the world to decrease time spent waiting at government offices. This innovative digital interaction, if adopted and deployed, can empower the next generation. Most of the previous research focused on developed countries, while developing countries are facing many complex obstacles related to socio-economic development, ineffective ICT strategies, and implementation challenges to meet electronic government project goals. We hope this review will help to give a better understanding about these elementary obstacle factors, which are related to infrastructure, political, economic, social, and legal issues, and users' perspectives. This study also provides suitable strategies to overcome these obstacles, to handle such issues in a better way. The nature of this study is an exploratory research has generated a list of possible strategies. It also supports policy makers, decision-makers, and government officials for the positive implementation and improvement of electronic projects.
\end{abstract}

Index Terms-E-Government, factors, obstacles, public sector, Pakistan, strategies, ICT infrastructure.

\section{INTRODUCTION}

Implementing e-Government projects have become a worldwide phenomenon through effective and innovative ICT based applications for the last decades. The goal of e-Government projects is tantamount to deliver better public services to enhance government efficiency with more digitally, economically and bring the public closer to the government in one advanced ICT platform. The Ministry of Information Technology, Pakistan was established in the year 2000 and introduced the e-Government directorate under this ministry [1], [2]. The government is taking place to use different correlated e-Government projects with five-year plans of 2005. Similar to the most of the developing countries, government of Pakistan also aspires to take initiatives and start e-Government projects in a whole country to provide better e-services in a more convenient and cost-effective way to the citizens of Pakistan [3]. Furthermore, the foremost priority for the Government of Pakistan is to adopt these projects for increasing the transparency and responsibility within government [4]. Strengthening the state ICT infrastructure and to enrich the e-Government projects in all the regions with the competency and effectiveness.

Initially these projects include civil computerized state databases, various connected registrations, and modern IT universities in all provinces. Furthermore, it includes on-line

Manuscript received January 22, 2015; revised April 24, 2015.

Zulfiqar Haider and Chen Shuwen are with the School of Management, Dalian University of Technology, Dalian, China (e-mail: zhaider23@hotmail.com, chensw@dlut.edu.cn).

Muhamamd Bux Burdey is with the Department of Public Administration, University of Sindh, Jamshoro, Pakistan (e-mail: mansoora79@yahoo.com). mapping and public cartographical data to establish automation of land record systems.

In addition, government has also introduced several e-service programs such as government web portals, compulsory computer training programs for all federal and provincial employees, etc. In order to implement these early projects the government is spending a huge amount in millions of dollars on e-Government projects [5]. It is noticeable that most of the major applications of e-Government projects have not been implemented successfully. This is because of technological and management complications in such projects, particularly in Pakistan's public sector [6]. On the other side of the e-Government project, success rate is highest in advanced countries as compared to third-world countries. According to [7], among overall projects, only 15 percent of e-Government projects are implemented on the satisfaction level, while 35 percent are totally failed. The rest of the 50 percent projects are partially failed because major goals were not reached up to that level due to undesirable results such as socioeconomic issues and inadequate ineffective ICT strategies that could occur mostly in developing countries. It is the part of the explanations of these failed projects lags far behind developed countries. In continuation to the earlier failure projects, government of Pakistan should consider and accept these core challenges for e-Government project obstacles in emerging countries such as Pakistan [8], [9]. The key aim of this study is to review the overall and existing published literatures and to find e-Government project obstacles.

Research problem: "What are the factors that become the obstacles for implementing e-Government projects in Pakistan public sectors?"

Generally, these obstacle factors are known as infrastructure, political, economic, social, and legal and users' perspectives, which, should directly be focused and addressed to improve and achieve the e-Government project's goals. Furthermore, it recommends proper strategies that must follow in order to recover e-Government project obstacles. To meet this target, concerned authorities must adopt smart strategies, take serious administrative decisions to emphasis, and implement in this context. It is expected that one-day, the Pakistani government policy makers and project managers will get success in the appropriate execution of e-Government projects. However, the focus of this study is to find out and contribute the factors that governing the e-Government project obstacles in perspectives of Pakistan's public sector.

\section{LITERATURE REVIEW}

\section{A. Theoretical Background}

E-Government is defined as connecting government digitally to serve and facilitate people with efficiency and 
effectiveness of different e-services. It provides various online government service under one ICT umbrella [10]. The projects of e-Government started around the world since the year 2000 and realize to offer customer's oriented services environment i.e. delivers better and faster services, increase more user's satisfaction and build trust on government e-services, etc. [11]. The development of e-Government towards public sector reform has become a creative instrument to produce the competence, strengthen competitiveness and increase transformation in the country [12]. A perfect execution of e-Government projects is one of the challenging tasks for all governments around the world, but it is not impossible. According to Pakistan e-Government, the directorate (EGD, 2011) claimed that there are more advanced ICT equipment's, resources and innovative technology adoption in progressive countries than emerging nations. Pakistan is supposed to be a developing government is in the growth stage of the e-Government projects. On the contrary, it is observed that e-Government implementation around the world can bring positive ICT structural improvements for better digital service condition and help to boost government executive performances [13]. Furthermore, it is also noted that electronic government projects could help the nations in development of the country through advanced technologies. The fruitful e-Governmental projects can raise government and citizen, the satisfaction, confidence and efficiency during utilization of e-Government services [14]. Previously published articles showed that planning, strategies and administrative affairs of ICT projects have disappointed the records for industrialized countries. However, a vigilant evaluation and acknowledged factors may affect the phenomenon of failure or success related to the e-Government projects [15]. It is important for the researcher to solve a complex puzzle and identify that why e-Government projects mostly failed in the development of itself or have low progress rate in the same while these projects have better results in the developed states [16]. The e-Government projects seem very attractive and digital service oriented, but it is difficult to implement such applications without facing any challenges and obstacles. In order to launch e-Government projects this could be a challenging assignment for adjustment in many governments, especially, in public organizations [17]. Emerging governments obtain limited resources to improve government performance. ICT infrastructure and enhanced electronic facilities to citizens [18]. Disparate facts, advanced countries are better in e-Government adoption and implementation. In this connection, it is debated that the success or failure of e-Government projects is not to be determined, whether it is carried out in advanced or developed countries. Lastly, the discussion finds that fewer well-established countries implemented this knowledge more positively [19]. Generally, complications are the common aspects of electronic project's development, such as risk factors, including technological, governmental behavioral, social, legal, economic, etc. It seems in most developing countries, during the implementation of the e-Government projects, some parliamentary influenced personnel find themselves as a decision-making authority in such projects. They are not ready for which often times, also they do not have sound knowledge for implementing such projects and even no professional or technical expertise [20], [21]. The Government of Pakistan is also facing many issues related to corruption such as sociopolitical issues etc. One of the leading examples among these issues is a misuse of official powers for personal interest in the governmental level and its affairs. The results obtained by these personal interests are weak because of unsatisfactory performance in public organizations [22]. In addition, the struggle to achieve supremacy among different political parties made the situation concerned to the administration worst in Pakistan. This shows that there is no stability in the current government policies, and frequently the policies are converted into short-term plans. Moreover, e-Government implementation is a national governmental project, which required stability and further generation of smart policies as well as it requires more funds to implement. The findings of the research study in [23]. Such challenges include the poor level of ICT infrastructure, poor security as well as privacy issues, cultural barriers and political willingness. The basic challenges to design e-Government projects can also be in the relation of facts \& figures, information, managerial and organizational issues, regulative and legal preconditions, Information Technology (IT), overall environmental and institutional factors [24]. The issues at the governmental level cannot be ignored such as the security and privacy issues and serious ICT technical challenges that are identified by most researchers in literature review [25]. Government systems are transforming in several emerging nations around the world and support its actual use, which requires suitable policies and regulative background to complete the phenomenon of e-Government in Pakistan. Such laws and regulations should be vigilant for covering all e-applications [26]. One way to develop ICT structure and organize e-Government projects effectively is to understand the procedures in terms of several phases such as projects in relation to the system development [27]. In general, system development methods and projects tend to have or depend on four core stages. First stage belongs to the designing of the whole project. The government must know how to design the system development methods in order to make its implementation possible. Second stage refers to the analysis of the project. The e-Government system is required to be analyzed for the purpose of its implementations. Third stage is for the construction of the project after the designing and analysis of the project. The e-Government projects must be constructed so that the fourth stage of its implementation can be taken into account for better services provided to citizens of Pakistan [28]. The e-Government may be linked directly to the respected chief dimensions of the good governance. The role of the government in tackling these issues, which must be high, and the policies of the government must reflect to be in the favor of e-Government adoption. In this regard, the factor of coherency of policymaking has a great extent on the e-Government adoption. The aim of this factor is to support better quality co-ordination among the different policy makers to the policy making both on the horizontal as well as on the vertical level. Another factor is participatory democracy, which supports the active and energetic participation of all policy makers in the process of 
policymaking. The efficiency, consistency, and effectiveness of the implementation to which the policy is to be held is also proved to be another perspective in the initial phases of the adoption of e-Government system in a better way. This phenomenon is earned in the political circumstances because of the support of the cooperation between the policy makers in favor of e-Government adoption and networking or establishing a set of connections in the policy implementation phases. Also to provide the fasten abilities to the implementation of the e-Government policies in a simpler, divergent, a factor of competitive edge to the other countries and more cost-effective way. There are also other factors, which are involved in the processes of e-Government policy making. Those factors are service efficiency, reducing the phenomenon of corruption, transparency in the policies for better amendments, and easy access to the information. The satisfaction level of the people to the government, quality of providing services, easy access to the website and its services, maximum information available on the web portal, faster means of communication are also involved. Many other issues involved in these processes are funding issues, political issues, lack of the financial resources, conflicts found between depth, family resistance, and most probably the cultural issues. The transparency and openness of political processes could be taken into account as it a broad access to the information is offered at a very low cost, with a guarantee of the high quality. Team leaders do not understand user needs whereas the project scope is still defined. Changes in the e-Government projects are very badly and poorly managed, the chosen IT modifications, business needs, and deadlines are unrealistic because of which the users are resistant and the sponsorship for implementing the e-Government projects is lost [29]. The managers of the project ignore the best practices by not hiring the technical human resource and when the time goes on, they learned from previous research. E-Government is the transformation of public sector to the internal and external relationships throughout the net enabled processes, information technology and communications to improve the government services delivery to the public participation and to the societies of the technical populations [30]. These projects are also designed to deliver a greater knowledge to the e-Government participants in order to facilitate access to the governing process and encourage deeper citizen participation [31]. The e-Government applications are based on online worked government, which could be linked to new technology with legal systems internally and connected to government information infrastructure externally with everything digital for everybody and every organization in the society [32]. Security's issues have become one of the main challenges for successful use of e-Government services and it will be able to solve when, there is a strong enough implementation process exists for the better development of the country Pakistan. All these basic functions are based on confidentiality, integrity and security of data transmission and the need of the processing e-Government projects should be trusted [33]. Moreover, in recent years the attention of politicians, political leaders, and scientists of the world has been drawn by the developed countries to enhance its resources with adoption of
e-Government system. In many countries, government of different countries has approached e-Government extensively. For the implementation of such system, governments of different countries are also devoting much resources and efforts [34]. However, a special kind of the leadership will be taken by overcoming these obstacles, which initializes to take the changes and eager to be involved by hiring the skilled human resources and making a relevant budget.

\section{B. E-Government Obstacles in Pakistan Public Sector}

Electronic Government Directorate (EGD), established in October 2002, was working under the Ministry of Information Technology, Pakistan. The first major e-Government project was set up in 2005 with the goal to enable citizens and businesses to get online access services in more efficient, professional and the cost-effective way. Moreover, it also helps to increase public sector performance by adopting innovative technologies. Providing 24 hour customer services through users friendly web access system, one can save a lot of time that could be helpful in managing records, paper free environment, availability of better network connectivity for the public as well as for private and at all governmental and organizational levels. This current study cannot ignore the other side of the coin, which is entirely different from the current situation of e-Government projects in Pakistan. A government almost failed to carry out their desired goals. Moreover, has been unsuccessful in setting up the mega e-Government projects in the country. Nowadays, it becomes a burning debate in third world countries, especially in Pakistan and its context that government is financing millions of rupees on ICT infrastructure, but the efforts provide the unsatisfactory and unpractical results [35], [36]. Furthermore, instead of the fact that the Government of Pakistan is facing so many obstacles and challenges related to socioeconomic development, implementation and improvement of e-Government projects in the public sector, public sectors of Pakistan. Such factors are ineffective strategies and actions, unfavorable policies, internal and external incompetence of the government, poor public sector performances, enchanting the quality of ITC design and infrastructure challenges, lack of financial resources, government vision and will of the citizens to implement such system in Pakistan [37]. However, these obstacles left a fundamental research problem for the contribution in existing research study, it can be a question mark for the country "What are the factors that become obstacles in improving e-Government projects in Pakistan public sectors?" One of the main reasons for these obstacles is less research in Pakistan and ineffective strategies of governments. From Table I, a clear view can be identified on these obstacles, which were already found in this research as the government announced to carry out e-Government projects with a five-year plan in 2005. In many developed countries, governments positively implemented and supported various e-Government projects for their nation such as an electronic voting system, electronic learning programs, electronic health technologies, online recruitment systems and other e-services for easy and reliable use of technology. 
TABLE I: DETAIL DESCRIPTION OF E-GOVERNMENT OBSTACLES IN PUBLIC SECTORS

\begin{tabular}{|c|c|c|c|}
\hline $\begin{array}{c}\text { Project name \& } \\
\text { References }\end{array}$ & Obstacles/factors & Description & Concluding remarks \\
\hline \begin{tabular}{l}
\multicolumn{2}{l}{ Electronic } \\
voting system \\
{$[38]$}
\end{tabular} & $\begin{array}{l}\text { Lack of poor technical project } \\
\text { management system, low IT } \\
\text { education, awareness, low } \\
\text { financial resources, untrained } \\
\text { human resources, low trust on the } \\
\text { government and etc. }\end{array}$ & $\begin{array}{l}\text { E-voting or electronic voting are same and used in } \\
\text { the system in order to casting and counting votes. } \\
\text { These type of tools can include optical scan, } \\
\text { punched cards and kiosks technologies etc. }\end{array}$ & $\begin{array}{l}\text { The mechanisms of the e-voting system } \\
\text { are not installed and implemented in the } \\
2013 \text { general election across Pakistan. } \\
\text { Particularly for the overseas Pakistanis, } \\
\text { the system was not installed hence, they } \\
\text { could not register }\end{array}$ \\
\hline $\begin{array}{l}\text { E-justice project } \\
\text { [39] }\end{array}$ & $\begin{array}{l}\text { Less political and governmental } \\
\text { support, ICT network problems, } \\
\text { Internal agency conflicts, } \\
\text { electronic justice plans, data } \\
\text { management system and ICT } \\
\text { infrastructure and etc. }\end{array}$ & $\begin{array}{l}\text { The project determination is to provide security } \\
\text { and ensure equal protection to the citizens of this } \\
\text { country under the law. The basic aim is to } \\
\text { strengthen the legitimacy of institutions in the } \\
\text { state. This task has to offer online access \& } \\
\text { facilitation to judges, lawyers and free online } \\
\text { access related to their legal information and cases } \\
\text { etc. }\end{array}$ & $\begin{array}{l}\text { Only few projects take initiation with low } \\
\text { capacity. Thousands of cases are pending } \\
\text { in Pakistan. If this system is up-graded } \\
\text { with the new technology and e-justice then } \\
\text { there might be the possibility of speedy } \\
\text { and quick justice delivery. }\end{array}$ \\
\hline $\begin{array}{l}\text { Federal } \\
\text { Government } \\
\text { Data Center } \\
{[40]}\end{array}$ & $\begin{array}{l}\text { Accessibility } \text { of data, less } \\
\text { cooperation between various } \\
\text { agencies, reconciliation data } \\
\text { problems, securities and etc. }\end{array}$ & $\begin{array}{l}\text { The basic purpose of FGDC is to improve the } \\
\text { speed of communications, sharing of data, } \\
\text { providing basic IT infrastructure to all the federal } \\
\text { divisions, ministries. }\end{array}$ & $\begin{array}{l}\text { The result supplied is low-level } \\
\text { inter-connectivity of federal divisions, } \\
\text { which could not be started. Hence, there } \\
\text { remains lack of connectivity with the } \\
\text { federation and its related units. }\end{array}$ \\
\hline $\begin{array}{l}\text { ATM (Kiosks) } \\
\text { Machines } \\
\text { [41] }\end{array}$ & $\begin{array}{l}\text { Less assembling unit operations, } \\
\text { slow networks, low maintenance, } \\
\text { processing and operating } \\
\text { problems, the communication gap } \\
\text { between the public and banks and } \\
\text { etc. }\end{array}$ & $\begin{array}{l}\text { National Database \& Registration Authority } \\
\text { (NADRA) has currently installed about } 30 \text { cashes } \\
\text { accepting ATMS around the country. These } \\
\text { ATMs are insufficient which allows and enables } \\
\text { the people of the country to deposit utility bills at } \\
\text { different locations. }\end{array}$ & $\begin{array}{l}\text { Unsatisfactory performance, especially in } \\
\text { the public sector. The focus of the } \\
\text { government should be in improving the } \\
\text { service quality, installing more ATMs at } \\
\text { the doorstep and ensure organized } \\
\text { securities. }\end{array}$ \\
\hline $\begin{array}{l}\text { Technical } \\
\text { support for ICT } \\
\text { project [42] }\end{array}$ & $\begin{array}{l}\text { Ineffective } \quad \text { strategies, technical } \\
\text { guidelines, } \quad \text { Technological } \\
\text { incompatibilities and etc. }\end{array}$ & $\begin{array}{l}\text { The basic aim of this project is to provide } \\
\text { technical and management services in the } \\
\text { capacity of governmental level in ICT among } \\
\text { different departments. }\end{array}$ & $\begin{array}{l}\text { Most projects among them are under } \\
\text { implementation. }\end{array}$ \\
\hline $\begin{array}{l}\text { Online } \\
\text { Recruitment } \\
\text { System [43] }\end{array}$ & $\begin{array}{l}\text { Unavailability of online recruiting } \\
\text { system, less attention and } \\
\text { willingness of employers and etc. }\end{array}$ & $\begin{array}{l}\text { It is the system which is easy to use, it improves } \\
\text { workforce and productivity, processes, customer } \\
\text { satisfaction and help in online recruitment access } \\
\text { and etc. }\end{array}$ & $\begin{array}{l}\text { No implementation has been achieved yet } \\
\text { and no mechanisms available in public } \\
\text { sector of Pakistan. }\end{array}$ \\
\hline $\begin{array}{l}\text { Online } \\
\text { Processing of } \\
\text { Hajj } \\
\text { Applications } \\
\text { [44] }\end{array}$ & $\begin{array}{l}\text { Less access to databases, low level } \\
\text { procedures to check the eligible } \\
\text { applications, \& assistances, issues } \\
\text { related to visa processing } \\
\text { applications, an ineffectual }\end{array}$ & $\begin{array}{l}\text { The ministry of information technology created } \\
\text { online processing of Hajj applications, status } \\
\text { tracking for arrangements, providing e-services } \\
\text { and registering their complaints regarding other } \\
\text { issues. }\end{array}$ & $\begin{array}{l}\text { It is inaccessible for users to find out detail } \\
\text { on the useful information on the online } \\
\text { portals of Hajj. Slow processing of } \\
\text { applications and late or no reply from the } \\
\text { concerned department. }\end{array}$ \\
\hline $\begin{array}{l}\text { E-services for } \\
\text { capital } \\
\text { development } \\
\text { Authority } \\
\text { (CDA) [45] }\end{array}$ & $\begin{array}{l}\text { Fewer count of computers, } \\
\text { networks, professionals, customer } \\
\text { care services, corruption, } \\
\text { bureaucracy involvement and } \\
\text { adoption of unfavorable policies } \\
\text { and etc. }\end{array}$ & $\begin{array}{l}\text { e-service is to keep updating the public of } \\
\text { approved or unauthorized housing societies and } \\
\text { its information schemes in Islamabad, Pakistan } \\
\text { and to check out the property tax and other } \\
\text { information. All these jobs are done by the CDA, } \\
\text { Pakistan. }\end{array}$ & $\begin{array}{l}\text { The government of Pakistan is required to } \\
\text { take effective measures to resolve chronic } \\
\text { issues related to frauds, online } \\
\text { registrations, service delivery and etc. }\end{array}$ \\
\hline $\begin{array}{l}\text { e-police services } \\
{[46]}\end{array}$ & $\begin{array}{l}\text { Less professionalize police force, } \\
\text { ICT infrastructure, and shortage } \\
\text { of electronic equipment lack of IT } \\
\text { human resource, less online } \\
\text { services and law enforcement } \\
\text { challenges and other low-level } \\
\text { facilities. }\end{array}$ & $\begin{array}{l}\text { E-policing project aimed equipping police with } \\
\text { the latest technology, increase speed coordination } \\
\text { among different law force agencies, supervision } \\
\text { with the better teamwork and access to the public } \\
\text { with timely responses and the imparting of legal } \\
\text { assistance. }\end{array}$ & $\begin{array}{l}\text { The project has not been fully } \\
\text { implemented in whole Pakistan. Despite } \\
\text { the fact that there is great, need for the } \\
\text { strong e-policing networks. The current } \\
\text { law and order situation in Pakistan is } \\
\text { unsatisfactory. }\end{array}$ \\
\hline $\begin{array}{l}\text { E-health } \\
\text { Technologies } \\
{[47]}\end{array}$ & $\begin{array}{l}\text { Lack of modern medical } \\
\text { apparatus, lack of technology, less } \\
\text { building infrastructures, } \\
\text { unfocused behavior of } \\
\text { government, } \\
\text { social and ethical awareness in } \\
\text { general public and etc. }\end{array}$ & $\begin{array}{l}\text { E-Health programs can be able to provide a wide } \\
\text { range of online telemedicine care knowledge, } \\
\text { skills and tools, which enables the users to follow } \\
\text { the information in order to support the delivery of } \\
\text { healthcare information and promotion. }\end{array}$ & $\begin{array}{l}\text { There is no real implementation of } \\
\text { e-health programs in public sector } \\
\text { hospitals in Pakistan. }\end{array}$ \\
\hline $\begin{array}{l}\text { E-learning } \\
\text { programs [48] }\end{array}$ & $\begin{array}{l}\text { Shortage of virtual classrooms, no } \\
\text { popularity and adoption of } \\
\text { e-learning projects in the country, } \\
\text { more technological issues and no } \\
\text { clear strategies or role of the } \\
\text { concerned departments to develop } \\
\text { this innovation and etc }\end{array}$ & $\begin{array}{l}\text { The regime of Pakistan is far behind in } \\
\text { e-scholarship course of studies such as distance } \\
\text { learning plans, which will be helpful in assisting } \\
\text { the students who are ill to attend school or who } \\
\text { dwell too far away from their schools. More } \\
\text { benefit is to reduce the travel time and travel costs } \\
\text { for off-campus scholars and then along. }\end{array}$ & $\begin{array}{l}\text { Electronic learning is the vital segment of } \\
\text { social and economic growth.Pakistani } \\
\text { policy makers need to take positive actions } \\
\text { in terms of establishing the digital schools, } \\
\text { colleges as well as universities and provide } \\
\text { other means of electronic learning. }\end{array}$ \\
\hline $\begin{array}{l}\text { Driving License } \\
\text { Issuance } \\
\text { Management } \\
\text { System } \\
\text { (DLIMS) } \\
\text { [49] } \\
\end{array}$ & $\begin{array}{l}\text { lack of technology, Less } \\
\text { professionalize traffic police to } \\
\text { cater technology, update } \\
\text { information is not available and } \\
\text { etc }\end{array}$ & $\begin{array}{l}\text { It is essential in automating the processes for } \\
\text { driving license issuance, renewal and upgrades. } \\
\text { This e-service is carried out throughout Pakistan. }\end{array}$ & $\begin{array}{l}\text { The implementation of this e-service } \\
\text { provides quick processing service and } \\
\text { aware the public with statistics to the } \\
\text { authorities. }\end{array}$ \\
\hline
\end{tabular}


TABLE II: E-GOVERNMENT INDEX RANKS IN SOUTH ASIAN COUNTRIES, 2014

\begin{tabular}{||c||c||c||c||c||c||c||}
\hline \hline Country & EGR & EGI & EPI & OSI & HCI & TII \\
\hline \hline Sri Lanka & 74 & 0.54176 & 0.64705 & 0.65354 & 0.73766 & 0.23412 \\
\hline \hline Maldives & 94 & 0.48129 & 0.27455 & 0.36222 & 0.68655 & 0.39516 \\
\hline \hline Iran & 105 & 0.45075 & 0.29411 & 0.37007 & 0.69922 & 0.29401 \\
\hline \hline India & 118 & 0.38343 & 0.62745 & 0.54333 & 0.46988 & 0.13723 \\
\hline \hline Bangladesh & 148 & 0.27572 & 0.39215 & 0.34645 & 0.38666 & 0.09414 \\
\hline \hline Pakistan & 158 & 0.25799 & 0.33333 & 0.32283 & 0.33377 & 0.11743 \\
\hline \hline Nepal & 165 & 0.23442 & 0.29411 & 0.15748 & 0.37744 & 0.16843 \\
\hline \hline Afghanistan & 173 & 0.19003 & 0.13725 & 0.18111 & 0.24188 & 0.14722 \\
\hline \hline
\end{tabular}

Source: United Nations survey report, 2014.

EGR: e-Government Rank, EGI: e-Government Index, EPI: e-participation Index, OSI- Online Service Index, HCI: Human Capital Index, TII: Telecommunication infrastructure index.

However, most of the developing countries such as Pakistan are still facing the aforementioned obstacles to carry out and improve the e-Government system in more professional and reliable way. There is an evident represent from Table I, which has pointed out few relevant obstacle factors in the e-Government project in Pakistan public sectors. It is important to note out for better understanding that one of the current obstacle factor belongs to the general election of Pakistan held in the year 2013. [50]. According to Election Commission, the main purpose of using this technology is to help municipal about casting and counting votes, reliable digital services and win the trust of the public by adopting this system for a fair election. Additionally, this system will help in transparency of voting, calculating the votes, make sure the exact identification of the prospective voters which would help in maintaining the record of the cast votes and will be supportive in deciphering the voting pattern. Unfortunately, the Pakistani government was unable to install the e-voting mechanism, and the voting was done on the same manual way resulting in the massive complaints of rigging and malpractices. These complained almost grown to the large propositions, when the leading politician and aspirant for the premiership in Pakistan, Imran Khan (politician) refused to accept the overall result of the 2013 general elections, mainly due to being factitious about the votes that were casted [51]. This situation has created a kind of political confusion in the administrative environment of Pakistan, and it could lead to the disturbance of the present government. It may also lead the government to the declaration of fresh elections in Pakistan. This example clearly shows that if there would have been the effective system of e-voting, then such unwarranted situation would have never stood up, and it would have guaranteed fair and a crystal unpolluted voting mechanism in Pakistan.

The above data in Table II indicates that the e-Government indexing of Pakistan is 158, and it is only higher than Nepal \& Afghanistan [52]. Consequently, the e-participation, online services, human capital and infrastructure are also lowest among the nations of the world. The table demonstrates the nations of Asian sub-continent and all are primary participations of SAARC (South Asian Association for Regional Co-Operation). It is really unfortunate that despite being the atomic state and having the best minds, Pakistan is turning much behind when it now comes in dealing with information technology related issues and show a weak enough performance. The e-Government does not apply in respect of the masses in a larger way and still the public sector enterprises are running on the manual system. Pakistan has to revive the positive relationship of having the state-of-the-art technologies and trained human resources to adopt e-Government projects in their department for better e-services. Apart from that, there is a calamitous need for the massive infrastructure which spread all over Pakistan to accommodate the high technological facilities to the citizens in terms of health, salaries, e-learning, reduction of paperwork, transportation and more ATM machines. Such implementation would boost overall e-Government activities and projects in the homeland. Otherwise, there could be a down sliding economic and social structure in Pakistan.

\section{A THEORETICAL FRAMEWORK FOR E-GOVERNMENT PROJECT OBSTACLES IN PAKISTAN}

In general, the obstacles in some of the e-Government project have already been recognized in Table I and Table II. As presented, the detail proposed in the aforementioned theoretical framework model would serve to find and uncover key reasons of these obstacle factors and help in the practical implementation process. Otherwise, it will be difficult for the government to meet project aims and stay fallen behind as compare to the other nations in ICT innovation infrastructure. These obstacle factors include infrastructure, political, economic, social, and legal and user's perspectives, which must be realized and successfully be started in the entire motherland with effective ICT strategies. As until this dynamic ingredients are addressed, there would be no system in terms of extending the massive networking of e-Government project structures. All the developed nations have been completely incorporated these factors in their e-Government projects. The developed nations in this regard have taken proper actions for the reorganization to see whether these obstacles are duly, addressed. South Korea can be taken into account for one of the classical examples for adoption of the relative e-Government projects, where these obstacles were overcome within the span of ten years, and once these obstacles were eradicated, the South Korean e-Government projects became a wide spread [53]. Today South Korea is found to be one of the most highly consumed nation on the earth with respect to adopting the e-Government 
applications, which are aimed for the betterment of the lives of their citizens [54]. Such, spirit is required from the perspectives of the policy makers in Pakistan. Where these obstacles are at the highest level and has the loopholes, which are needed to be carefully followed so that the Pakistani masses take full advantage of the ICT, similar to the other nations who are making the most of these types of projects related to e-Government. The detailed evaluation of these factors along with the Fig. 1 and Fig. 2 are shown below. The justification of identifying affected factors related to projects of e-Government and its obstacles in Pakistan where facilities are in an undeveloped state.

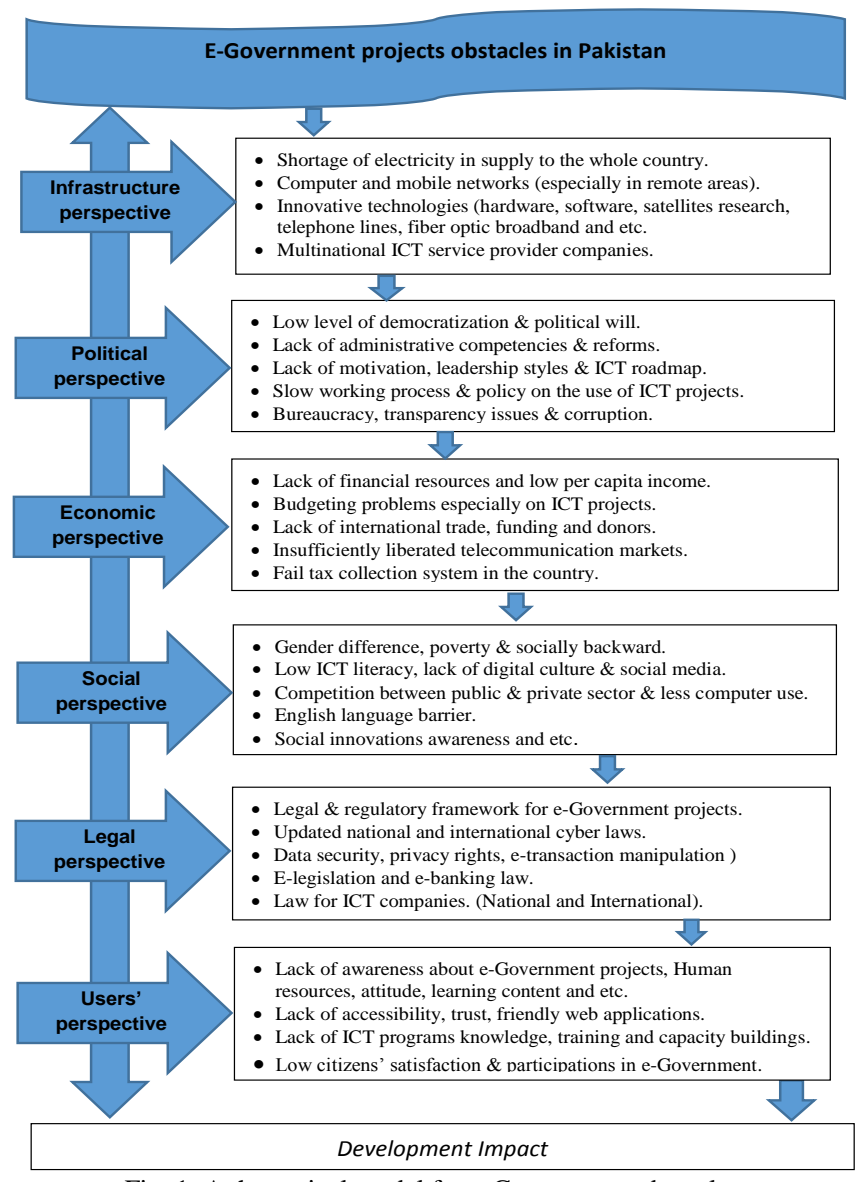

Fig. 1. A theoretical model for e-Government obstacles.

\section{A. Infrastructure Perspective}

In developing countries, the condition of physical infrastructure of ICT is very poor and therefore these countries are facing issues in many resources such as the deficit of electricity, finance, hardware and software the use of creative technologies in all sectors [55]. The installation of hardware and purchasing the relevant software in the government departments and public organizations is not just a matter of setting up the system that provide the services and facilities related to the networking with the set of different connections. In order to make the most of these services that users of the ICT infrastructure such as citizens, businesses and the government itself have to make themselves enough skilled and e-ready to participate in the opportunities. Besides that, infrastructure of ICT is not user-friendly and is unprofessionally, managed in most of the ministries of governmental websites. It is, therefore, difficult for large population of the country to make the most from such infrastructure as well as from governmental websites and disabilities to reach on the success level of implementation of such e-Government system. Timely updating of such websites is really an important aspect to indulge the people of its homeland in touch with e-Government. It is a key requirement to build an appropriate ICT infrastructure in the country. Furthermore, computer network systems and security applications, and adoption of innovation technologies are needed which could secure all types of an online system such as payment transactions relevant to e-Government projects. Otherwise, it will face serious technical obstacles that are shown in Fig. 1.

\section{B. Political Perspective}

From Fig. 1, it can be seen that e-Government projects are carried out in the complex situation and are facing a number of obstacles or political problems, which make brutal effects on the organizations of public sector and its performances [56]. It is concerned to the several political parties with the struggle for power that could make the situation worst for the political aspects of Pakistan. It will then, result in inconsistent and conflicting policies of the governments and result in the policies that are often proven to be the short-term. Since, implementation of e-Government is a governmental project, therefore, the government of Pakistan is responsible to provide the funds (Dada, 2006). Hence, it is difficult to govern these projects due to the political parties and politics, which are not stable in the country. Unfortunately, when a project initializes by one government for the betterment of the country the next regime takes over resulting in immediate stopping of that project. Often, the reason for stopping such project is not more on political but on the cost or benefit grounds and other personal issues.

\section{An Economic Perspective}

There is no or a slight chance to end up the projects of e-Government successfully in Pakistan because of no or enough funds. The main economic reason for Pakistan to have been unsuccessful at e-Government level is that Pakistan is circulating around the problems and issues related to the terrorism and has been tackling the troubles generated by terrorists for a number of previous years. The huge amount of national savings and earnings are spent by the government of Pakistan to tackle such obstacles of terrorism, which left over the enough savings for the e-Government projects. Reduction in the resources for its deployments results in bad economic development with the e-Government perspectives. The impact of economics has great significance on ICT projects in any country. E-Government projects can prove to be essential in contributing and enhancement of the efficiency of the economy as well the GDP growth is also having more potential in the same. The creative industries impact and effect as a whole on the productivity of the private and public sector in particular. Therefore, it is most essential for the government to overcome the aforementioned obstacles and generate more revenue for smoothly running e-Government projects to prove the e-Government projects as a positive symbol in Pakistan. 


\section{Social Perspective}

Social obstacles in ICT track include all aspects of social issues that are impacted by ICT projects affecting organizational structures and hence, could make a strong effect on the society. Most of these obstacles can be seen in Fig. 1. A large proportion of the population is not literate enough in Pakistan to cater the e-Government related projects and finds the use of the computer and internet more difficult for them (Kundi et al., 2009). There is a definite effect of the high illiteracy rate and poor level of the basic education in Pakistan, which contributes in affecting the e-Government adoption and its services. The low salary packages for the employees at the governmental level are another issue, which stops the adoption of e-Government in Pakistan. Hence, the interest of the skilled people is not much enough to join the public sectors and provide their services. All these obstacles are the result for the people to get involved in the human psychological factors. Thus, the e-Government projects will not produce any errors with the literate citizens otherwise, it will be terminated to achieve its targets. It is as well important for e-Government projects to promote an e-culture in the society and give more importance to their users.

\section{E. Legal Perspective}

Use From this situation, it incorporates a set of obstacles related to various legal aspect issues about developing ICT and implementing e-Government projects [55]. These degrade e-Government projects linked to international and regional levels, such as network crime, data privacy \& security dangers, hacker attacks, viruses, masquerades of unauthorized identity, computer forgery and international cyber-crime and others. Additional obstacles relevant to legal law in information engineering and e-transaction process manipulations threats to the economical aspects of the country.

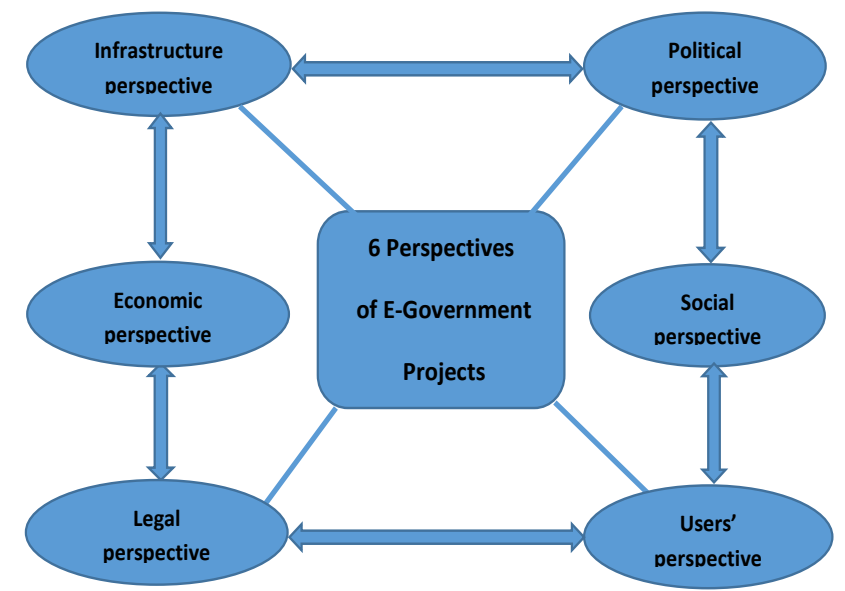

Fig. 2. A graphical model of 6-perspectives of E-Government projects obstacles.

\section{F. Users'Perspective}

Users' are one of the most important aspects in this regard because they expect to get high quality accessible services and friendly operation of e-Government services [9]. A core of every e-Government services must understand user's need and expectations at individual as well as at congregational level. The government should introduce several e-learning programs at all levels where participation took place because users are most valued participator actor or the backbone in the development of e-Government projects. A particular attributes of attitude towards ICT based interaction between e-Government and users. Although, governments must develop more consideration and offer occasions for users and get involved in e-Government projects.

\section{EFFECTIVE STRATEGIES MUST Follow IN ORDER tO Put the E-Government Project Obstacle Perspectives}

Recently, the successful implementation and development of e-Government projects have become a countrywide challenge for the Government of Pakistan. However, this whole scenario has left a question for the policy makers and decision makers, who are associated with these projects. The question arises here that how to follow and carry out operative and effective policies or strategies to improve e-Government projects obstacles. Consequently, in the light of the above-mentioned theoretical framework for e-Government project obstacles the strategies describes a set of assurances to implement action to do an overall vision as defined in figure 1. In addition, there is a need to define and to remind the perspectives here that the technical, political, economic, social, and legal and users' perspectives are the six perspectives on which the wall of the e-Government projects stood up. This research offered some core strategies for e-Government project where the obstacles to be resolved which are as follows.

\section{A. Infrastructure Perspective Strategies}

Development authorities need to have a strong focus to set up sound ICT infrastructure in the country. Make sure that the active e-Government projects, its implementation with more accessibility and availability of servicing all types of users' must occur digitally. The strengthen ICT networks, hardware equipments and communication channels among different ministries, public and private sectors at all levels must be available. Furthermore, it is essential to improve electronic projects with more efficient and professional way i.e., develop an ICT system in which the security applications, secure payment structures are faster and cost-effective internet connectivity is proved to be easier access to all the web portals on the governmental level. ICT in Pakistan can create an environment in Pakistan in which an individual is able to show his or her potential to increase the productivity in an effective manner including the public sector organizations. The better performance of ICT by the government with respect to its use may prove to be fundamental in linking the functions of the governmental organizations as well as private and public sectors of Pakistan. An environment in which the technology is a base for the growth and development can be form by the adoption of e-Government throughout the use of ICT.

\section{B. Political Perspective Strategies}

A government must take all political parties on board at the time of developing the most comprehensive national projects policies or strategies. This strategy opens to the new doors in order to enable additional collaboration among political 
parties. In addition, it will also serve to put opponent party pressures and other policy conflicts. However, the Pakistani government has a painful history of past, about political instability in the country. The government often has been changing in Pakistan i.e. when a project initializes by one government for the betterment of the country the next regime takes over resulting in immediate stopping of that project. Often, the reason for stopping such project is not more on political but on the cost or benefit grounds and other personal issues. The government of Pakistan must manage and maintain a test to see whether it can be able to use e-Government services in the form of technology in order to operate the technology in a more effective and efficient way. The test will also provide the basis to check whether the provided service and programs are able to cater the manual task of the people in a more effective and efficient way.

\section{Economic Perspective Strategies}

Developing countries still have lower domestic income and limited availability of various resources when compared to other developed countries. Many challenges faced by developing countries such as poor economic strategies, bad governance, corruption, and government initiatives. Despite of the top government authorities, it should build up more federal interaction based trade programs between other countries. A government should think on more domestic transactions and business connections by using $\mathrm{G} 2 \mathrm{G}$ (Government to Government) or e- commerce technology, which will help to generate more revenue for the nation. Pakistan is able to promote its ICT in a way to recognize the power of ICT in Pakistan. The government of Pakistan finds the ICT infrastructure as supportive to the businesses in order to improve its efficiency. Enabling ICT infrastructure will enable to reduce the issues of the poverty in the citizens of every state in Pakistan with the help of creating an environment in which the government avoiding recession will be able to generating the new and fresh market jobs.

\section{Social Perspective Strategies}

The core strategies in this aspect are necessary to educate the nation without gender differences and develop the updated e-Government projects with contemporary technologies. Moreover, it needs to build more e-projects in remote areas. There is also the need to encourage technical and skilled people, in training of exchange programs for ICT expert employees and managers of governmental organizations, who are directly in the communication with improvement of e-Government projects in Pakistan. In addition, the social perspective strategies are to arrange workshops and academic seminars with mass communication channels for e-culture promotion and ICT development at local and national level.

\section{E. Legal Perspective Strategies}

One of the achievements of e-Government projects extremely depends on ensuring an appropriate legal framework for their users; it should be incorporated as a set of protected laws, rules and regulations with effective policies. These various legal aspects must belong to the national or international level to ensure the security and privacy of the customers, projecting business \& human rights. These are associated with various network crimes, personal data in the debit or credit cards, privacy \& security dangers, copyright law, hacker attacks, viruses, unauthorized identity, computer forgery, banking system, digital signature, international cybercrime and others issues concerned with the clients. After focusing on these strategies and framework or laws, the government of Pakistan will increase the level of users' satisfaction towards internet and data security issues.

\section{F. Users'Perspective Strategies}

According to the annual report of Pakistan's telecommunication authority (PTA) now, there are approximately thirty millions Internet users in Pakistan. The majority of them cannot use existing e-Government services for their personal purposes. To understand the deep effect of this issue, human behavior is of a complex assignment for policy makers which they have to study very deeply therefore, government should offer friendly users, innovative all e-services under one digital umbrella. In this way, e-Government projects can bring closer to the public. All concerned authorities must accept and recognize all web users as a valued customer and give preferences to solve their digital problems and others.

\section{CONCLUSION AND FUTURE WORK}

The research in this study is tantamount to explore the obstacles for implementing major e-Government projects in third world countries. These major projects related to the e-Government which, has been proved to be a challenging assignment are failed to meet organizational and developmental outputs, particularly in Pakistan. However, effective implementation and better development of e-Government projects in Pakistan are not free of any barriers or obstacles especially in mega electronic projects. Most pointed major obstacles are technical, political, economic, social, legal, users, lack of adequate strategies and other perspectives. This study tries to show those key obstacle factors that are related to the implementation and improvement in the e-Government system and need to pay more attention to the progress of e-Government projects, promptly and accurately. Subsequently, there is a great necessity for the government of Pakistan to adopt e-Government immediately. The government of Pakistan must plan to design the fruitful strategies properly for the benefits of its citizens as well as for the businesses and public sector reforms. The beneficial strategies must be designed keeping the public reforms of Pakistan in terms of availability, quality, accessibility, and fast delivery of reliable government service.

\section{REFERENCES}

[1] A. Bhutto, I. R. Pir, and M. A. Qazi, "Indicators for science and technology policy in Pakistan: Entering the science, technology and innovation paradigm," Science and Public Policy, vol. 39, no. 1, pp. 1-12, 2012.

[2] H. Rahman, "Framework of e-governance at the local government level," Comparative e-Government, pp. 23-47, 2010.

[3] M. Asgarkhani, "The effectiveness of e-service in local government: A case," Asymptotic and Computational Methods in Spatial Statistics, pp. 1-22, 2009. 
[4] S. Abdallah and I. S. Fan, "Framework for e-Government assessment in developing countries: case study from Sudan," International Journal on Electronic Government, vol. 9, no. 2, pp. 158-77, 2012.

[5] D. Y. M. Lim and R. V. James, "Regional organizations and international politics: Japanese influence over the Asian Development Bank and the UN Security Council," World Politics, vol. 65, no. 1, pp. 34-72, 2013

[6] M. Alryalat, Y. K. Dwivedi, and M. D. Williams, "An analysis of electronic government research from the perspective of developing countries," International Journal of Indian Culture and Business Management, vol. 7, no. 4, pp. 461-527, 2013.

[7] M. K. Othman, N. M. Yasin, and N. A. Samelan, Factors Influencing the Adoption of E-Services in Malaysia, 2013.

[8] M. Rehman, V. Esichaikul, and M. Kamal, "Factors influencing e-government adoption in Pakistan," Transforming Government: People, Process and Policy, vol. 6, no. 3, pp. 258-82, 2012.

[9] S. N. A. Kazmi, "Factors influencing e-governance implementation: Issues and challenges in Pakistan," in Proc. the Fifth International Conference on Digital Information Management, 2010.

[10] F. Wang et al., "From potential users to actual users: Use of e-government service by Chinese migrant farmer workers," Government Information Quarterly, vol. 29, 2012.

[11] Z. Haider, C. Shuwen, and S. Hyder, "Citizens' participation in e-government services: A comparative study of Pakistan \& Singapore," IOSR Journal of Electronics and Communication Engineering, vol. 9, no. 6, pp. 35-38.

[12] J. T. Snead and E. Wright, "E-government research in the United States," Government Information Quarterly, vol. 31, no. 1, pp. 129-136, 2014.

[13] T. Schuppan, "E-government in developing countries: Experiences from sub-Saharan Africa," Government Information Quarterly, vol. 26 , no. 1, pp. 118-127, 2009.

[14] A. Sreejith, P. V. Ilavarasan, and M. P. Gupta, "Determinants of citizens' electronic participation: insights from India," Transforming Government: People, Process and Policy, vol. 8, no. 3, pp. 447-472, 2014.

[15] V. T. A. S. Venkatesh, and S. Venkatraman, "Understanding e-government portal use in rural India: Role of demographic and personality characteristics," Information Systems Journal, vol. 24, no. 3, pp. 249-269, 2014.

[16] C. Antonio and J. Hesse, "E-government in the making: An actor network perspective," Transforming Government: People, Process and Policy, vol. 9, no. 1, 2015.

[17] N. R. Nengovhela, The Performance of Government IT Officers in E-Government Policy Implementation, 2013.

[18] Y.-J. Hu, Z.-H. Lv, J.-P. Wu, K. Janowicz, X.-Z. Zhao, and B.-L. Yu, "A multistage collaborative 3D GIS to support public participation," International Journal of Digital Earth Ahead-of-Print, pp. 1-23, 2013.

[19] C. G. Mkude and M. A. Wimmer, "Strategic framework for designing e-government in developing countries," Electronic Government, pp. $148-162,2013$.

[20] D. Sarantis, S. Smithson, Y. Charalabidis et al., "A critical assessment of project management methods with respect to electronic government implementation challenges," Syst. Pract. Act. Res., vol. 23, no. 4, pp. 301-321, 2010.

[21] M. J. Ahn and S. Bretschneider, "Politics of e-government: E-government and the political control of bureaucracy," Public Administration Review, vol. 71, no. 3, pp. 414-424, 2011.

[22] S. Soomro and M. F. Memon, Corruption: Socio-Political Perspective in Pakistan, p. 101.

[23] R. Alghamdi, S. Drew, and M. Alshehri, "Strategic government initiatives to promote diffusion of online retailing in Saudi Arabia," in Proc. Sixth International Conference on Digital Information Management, 2011.

[24] H. Chourabi, T. Nam, S. Walker et al., "Understanding smart cities: An integrative framework," in Proc. 45th Hawaii International Conference on System Science, 2012, pp. 2289-2297.

[25] M. A. Alshehri and S. Drew, "E-government fundamentals," in Proc. the IADIS International Conference on ICT, Society and Human Beings, 2010.

[26] N. Helbig, J. G.-G. Ramón, and E. Ferro, "Understanding the complexity of electronic government: Implications from the digital divide literature," Government Information Quarterly, vol. 26, no. 1, pp. 89-97, 2009.

[27] C. M. L. Chan, R. Hackney, S. L. Pan, and T.-C. Chou, "Managing e-Government system implementation: A resource enactment perspective," European Journal of Information Systems, vol. 20, no. 5, pp. 529-541, 2011.

[28] C. Ø. Madsen, J. B. Berger, and M. Phythian, "The development in leading e-government articles 2001-2010: Definitions, perspectives, scope, research philosophies, methods and recommendations: an update of heeks and bailur," Electronic Government, pp. 17-34, 2014

[29] T. Aggeliki, H. Lee, Z. Irani, V. Weerakkody, I. Osman, A. A. Latif, and T. Medeni, "Evaluating e-government services from a citizens' prespective: A reference process model," in Proc. Mediterranean \& Middle Eastern Conference on Information Systems, 2012.

[30] J. R. C. Pachón, J. L. M. Cegarra et al., "E-government and citizen's engagement with local affairs through e-websites: The case of Spanish municipalities," International Journal of Information Management, vol. 32, no. 5, pp. 469-478, 2012.

[31] F. Lin, S. S. Fofanah, and D. Liang, "Assessing citizen adoption of e-government initiatives in Gambia: A validation of the technology acceptance model in information systems success," Government Information Quarterly, vol. 28, no. 2, pp. 271-279, 2011.

[32] S. Krishnan, T. S. Teo, and V. K. Lim, "Examining the relationships among e-government maturity, corruption, economic prosperity and environmental degradation: A cross-country analysis," Information \& Management, vol. 50, no. 8, pp. 638-649, 2013.

[33] J. Marijn, Y. Charalabibis, G. Kuk, and T. Cresswell, "Guest editors" introduction: E-government interoperability, infrastructure and architecture: State-of-the-art and challenges," Journal of Theoretical and Applied Electronic Commerce Research, vol. 6, no. 1, 2011.

[34] F. A. Zeleti, "The progress and obstacles of implementing and improving e-Government in Islamic Republic of Iran,” Lappeenranta University of Technology, 2010.

[35] M. I. Arfeen and N. Khan, "Factors influencing e-governance in Pakistan: case study of e-Governance projects in Balochistan," in Proc. the 13th Annual International Conference on Digital Government Research, 2012.

[36] S. Ahmed and J. Diesner, "Information network analysis to understand the evolution of online social networking sites in the context of India, Pakistan, and Bangladesh," Growth, vol. 3, 2012.

[37] M. N. Baqir, P. Palvia, and H. Nemati, "Evaluating government ICT policies: An extended design-actuality gaps framework," in Proc. the Second Annual SIG GlobDev Workshop, 2009.

[38] D. Folasade, "Towards the deployment and adoption of Location-based services for optimal mobile communication operations in Africa," The African Journal of Information Systems, vol. 4, no. 2, 2012.

[39] A. Zorer, E-Infrastructures and E-Services on Developing Countries, 2010.

[40] M. O. Ahmad, J. Markkula, and M. Oivo, "Factors influencing the adoption of e-government services in Pakistan," in Proc. the Ninth European, Mediterranean \& Middle Eastern Conference on Information Systems, 2012.

[41] F. Khan, B. Zhang, S. Khan et al., "Technological leap frogging e-government through cloud computing," in Proc. the 4th IEEE International Conference on Broadband Network and Multimedia Technology, 2011.

[42] L. Chun, "The myth of informatization in rural areas: The case of China's Sichuan province," Government Information Quarterly, vol. 29 , no. 1 , pp. $85-97,2012$

[43] H. Sirajul and P. Pathrannarakul, "E-government towards good governance: A global appraisal," Journal of E-Governance, vol. 36, no. 1, pp. 25-34, 2013

[44] S. Iqbal and D. I. A. Qureshi, "E-government-trends and challenges from the perspective of developing nations with focus on Pakistan," Chief Patron.

[45] F. Hameed, H. Abbas, M. Pasha et al., "Feasibility analysis for deploying a centralized information exchange infrastructure in Pakistan," in Proc. SIG Globdev 5th Annual Conference, 2012.

[46] M. A. Metawe'e, A. N. Z. Rashed et al., "Unguided nonlinear optical laser pulses propagate in waters with soliton transmission technique," International Journal of Multidisciplinary Sciences and Engineering, vol. 2, no. 1, pp. 1-10, 2011.

[47] K. Faria and M. Rehman, "E-learning Adoption Model: A case study of Pakistan," Life Science Journal, vo. 11, no. 4, 2014.

[48] H. Bokhari and M. Khan, "Digitisation of electoral rolls: Analysis of a multi-agency e-Government project in Pakistan," in Proc. the Sixth International Conference on Theory and Practice of Electronic Governance, 2012

[49] R. Musarrat and M. Ibrahim, "Democratization in South Asia: A case study of India and Pakistan (1988-1999)," International Journal of Learning and Development, vol. 3, no. 1, pp. 254-276, 2013. 
[50] M. I. Arfeen and N. Khan, "Public sector innovation: case study of e-government projects in Pakistan," The Pakistan Development Review, pp. 439-457, 2009.

[51] R. M. Ramli, "Malaysian e-government: issues and challenges in public administration," International Proceedings of Economic Development and Research, vol. 48, no. 2, pp. 19-23, 2012.

[52] S. Shah, A. Khan, and M. Khalil, "Project management practices in e-government projects: A case study of electronic government directorate (EGD) in Pakistan," International Journal of Business and Social Science, vol. 2, no. 7, pp. 134-142, 2011.

[53] G. F. Khan, J. Moon, H. W. Park et al., "A socio-technical perspective on e-Government issues in developing countries: A scientometrics approach," Scientometrics, vol. 87, no. 2, pp. 267-286, 2011.

[54] Driving Lisence Issuance Management System. (2015). [Online]. Available: http://www.trafficpolice.punjab.gov.pk/dlims

[55] M. Janssen, Y. Charalabibis, G. Kuk, and T. Cresswell, "Guest editors' introduction: E-government interoperability, infrastructure and architecture: state-of-the-art and challenges, "Journal of Theoretical and Applied Electronic Commerce Research, vol. 6, no. 1, 2011.

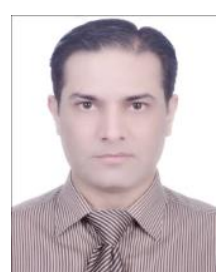

Zulfiqar Haider is currently working as an assistant professor in the Department of Public Administration, University of Sindh, Jamshoro, Pakistan. He earned a bachelor degree in 1999 and a master degree in 2001 from University of Sindh., then he got the MS degree in 2011 from Tsinghua University, Beijing, China. Currently he is pursuing his Ph.D. research at Dalian University of Technology, China. His research interests include e-government, new public management and public policy.

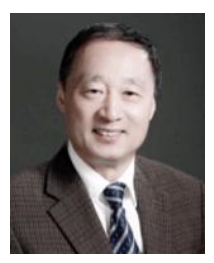

Chen Shuwen received his undergraduate degree from Dongbei University of Finance \& Economics, a graduate degree from Jilin University, and a doctorate degree from Jilin University. China. He is a qualified PRC lawyer and have practicing at Liaoning Tianhe Law Firm. In 1992 he became the director of Benxi City Commission for Restructuring the Economic Systems and has worked on various positons. Since 2003, he has been the professor and the tutor for doctorate students at Faculty of Management and Economics of Dalian University of Technology, China. His current research interests include human resource management, leadership and public administration

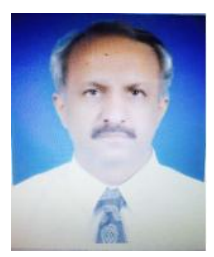

Muhamamd Bux Burdey is currently performing his duties as the chairman and a professor in the Department of Public Administration, University of Sindh, Jamshoro, Pakistan. He has worked as a lecturer from 1991 to 2003. He became an associate professor in 2011. He also has worked on various administrative position in University of Sindh. He received his master degree from University of Sindh in 1987, the M.Phil degree in 2000 from University of Bergen Norway and the Ph.D. degree from University of Karachi, Pakistan in 2004. His area of research interest is local government, public administration, and human resource management. 